\title{
Pelatihan Layanan Konseling Individual Bagi Guru Bimbingan dan Konseling
}

\section{Individual Counseling Service Training for Teachers and Counselings}

\author{
Heni Sulusyawati* Juwanto
}

Prodi Bimbingan dan Konseling Universitas Prof. Dr. Hazairin SH, JL. A. Yani No. 1 Bengkulu, Indonesia

\begin{tabular}{|c|c|}
\hline Info Artikel & ABSTRAK \\
\hline $\begin{array}{l}\text { Diterima } 26 \text { Agustus } 2019 \\
\text { Ditelaah } 31 \text { Maret } 2020 \\
\text { Disetujui } 28 \text { Juni } 2020 \\
\text { Tersedia daring } 30 \text { Juni } 2020 \\
\text { *Penulis untuk korespondensi } \\
\text { henisulusyawati9@ gmail.com } \\
\end{array}$ & $\begin{array}{l}\text { Memasuki era globalisasi, peran konseor di sekolah sangat penting. Oleh sebab itu, } \\
\text { kegiatan pelatihan layanan konseling individual ini dilakukan. Kegiatan pelatihan } \\
\text { layanan konseling individual ini bertujuan untuk meningkatkan pemahaman konselor di } \\
\text { Sekolah Menengah Pertama Muhammadiyah Terpadu Bengkulu dalam melakukan } \\
\text { konseling individual. Adapun metode yang digunakan dalam pelatihan ini yaitu } \\
\text { ceramah, tanya jawab, diskusi, dan praktik. Peserta yang dilibatkan dalam pelatihan ini } \\
\text { yaitu Konselor di SMP Muhammadiyah Terpadu Bengkulu. Hasil kegiatan pelatihan } \\
\text { layanan konseling individual berjalan dengan baik hal itu ditunjukkan dari hasil angket } \\
\text { sebelum diberikan pelatihan layanan konseling individual berada pada kategori tidak } \\
\text { paham dengan persentase } 28,70 \% \text {. Setelah diberikan pelatihan layanan konseling } \\
\text { individual adanya peningkatan pemahaman Konselor dalam melakukan konseling } \\
\text { individual berada pada kategori paham dan mampuh melakukan praktik konseling yang } \\
\text { baik, dengan capaian persentase } 89,81 \% \text {. }\end{array}$ \\
\hline & ABSTRACT \\
\hline $\begin{array}{l}\text { Keywords: } \\
\text { Individual Counseling, } \\
\text { Counselor }\end{array}$ & $\begin{array}{l}\text { In this globalization era, the role of the concept in schools is very important. Therefore, } \\
\text { this individual counseling training activity was carried out. This individual counseling } \\
\text { service training activity was aimed to increase the understanding of counselors at } \\
\text { Muhammadiyah Integrated Junior High School Bengkulu in conducting individual } \\
\text { counseling. The methods used in this training were lectures, questions and answers, } \\
\text { discussions, and practices. Participants involved in this training were counselors at } \\
\text { Muhammadiyah Integrated Junior High School Bengkulu. The results of the training for } \\
\text { individual counseling services went well, they were shown from the results of the } \\
\text { questionnaire before being given training for individual counseling services in the } \\
\text { category of not understanding with a percentage of } 28.70 \% \text {. After the training in } \\
\text { individual counseling services was given to the students, there was enhancement in } \\
\text { understanding of counselors in conducting individual counseling. They were in } \\
\text { understanding category, and they were able to do good counseling practices with an } \\
\text { achievement percentage of } 89.81 \% \text {. }\end{array}$ \\
\hline
\end{tabular}

ISSN 2685-0354 (Media Online). Diterbitkan oleh Universitas Prof. Dr. Hazairin, SH. Ini merupakan jurnal bebas akses di bawah lisensi Creative Commons Atribution 4.0 International (https://creativecommons.org/licenses/by/4.0

\section{PENDAHULUAN}

Maraknya kenakalan remaja saat ini, khususnya di SMP Muhammadiyah Terpadu Kota Bengkulu berdasarkan hasil wawancara pada hari senin, 8 April 2019 dengan kesiswaan Ibu Yulisnawati, S.Pd. masih ditemukan peserta didik yang mengabaikan kedisiplinan baik dalam kegiatan pembelajaran maupun dalam kedisiplinan tata tertib di sekolah. Selain itu hasil observasi yang dilakukan pada hari selasa, 11 April sampai dengan Jum'at 12 April 2019 ditemukan peserta didik yang tidak membuat tugas, minat belajar rendah, adanya peserta didik yang bolos pada saat jam belajar, tidak datang kesekolah tanpa keterangan, berkelahi antar teman, bermain game pada saat jam belajar, kurang sopan dalam berkomunikasi dengan guru dan dengan teman sebayanya. Hasil penelitian Septiana (2019) menunjukkan bahwa prilaku prososial siswa di era revolusi industri 4.0 semakin menurun sehingga diperlukan arahan 
dan bimbingan baik dari para Guru maupun konselor untuk mengembalikan fitrah individu sebagai mahluk sosial. Hasil penelitian Jannah dan Sari (2019) menunjukkan kecanduan game pada siswa secara umum berada pada kategori tinggi. Selanjutnya hasil penelitian Damayanti dan Setiawan (2013) menyatakan bahwa perilaku membolos dapat mempengaruhi akademik di sekolah, karena tidak dapat menyelesaikan topik mata pelajaran pada hari itu. Adiningtiyas (2017) mengemukakan bahwa game online memiliki dampak yang negatif terhadap pengguna, untuk mengatasi dampak negatif game online tersebut diperlukan adanya peran konselor di sekolah agar dapat membantu siswa melalui layanan konseling individual. Sementara di SMP Muhammadiyah Terpadu belum ada tenaga Konselor yang berlatar belakang Sarjana Pendidikan Bimbingan dan Konseling, melainkan yang yang menjadi Konselor di SMP Muhammadiyah Terpadu tersebut yaitu Guru Mata Pelajaran. Guru Mata Pelajaran tersebut mengalami kebingungan dalam menangani dan membantu siswa-siswi di sekolah. Adanya keluhan dan keterbatasan Guru Mata pelajaran dalam melakukan konseling dengan siswa. Konseling yang dilakukan dengan siswa selama ini cenderung hanya menasehati siswa-siwi saja, tanpa melalui lima tahapan dalam konseling yaitu pengantran, penjajakan, penafsiran, pembinaan, dan penilaian. Nasehat itu keinginan dari konselor belum tentu keinginan klien atau siswa, apabila Konselor hanya cenderung memberikan Nasehat kepada klien atau siswa pada saat proses konseling individual maka akan mengakibatkan hasil konseling menjadi tidak efektif, karena dalam konseling individual nasehat hanya sedikit diberikan oleh Konselor dengan klien, dan nasehat itupun diberikan ketika klien benar-benar memintaknya kepada Konselor. Stein \& DeBerard 2010) mengemukaan Guru BK yang tidak berlatar belakang pendidikan S1 BK dapat melakukan pengembangan kegiatan profesional layanan konseling individual dengan mengikuti berbagai pelatihan dan aktivitas keprofesionalan layanan konseling individual lainnya

Prayitno, Wibowo, Marjohan, Mugiyarso dan Ifdil (2015) mengemukakan sebagai pendidik, Guru BK atau konselor menyelenggarakan kegiatan pembelajaran melalui layanan, salah satu layanan yang ada dalam bimbingan dan konseling adalah layanan konseling individual. Layanan konseling individual ini digunakan oleh Konselor dalam membantu siswa-siswi yang mengalami masalah pribadi, sosial, belajar, dan karier. Selanjutnya hasil penelitian Asmaryadi (2017) mengemukakan bahwa upaya guru bimbingan dan konseling dalam meningkatkan hubungan sesama kedewasaan mencapai nilai yang diharapkan dalam kategori bagus. Artinya upaya Guru Bimbingan dan Konseling dalam membantu siswa agar dapat berkembang secara optimal.

Apabila keluhan atau masalah yang dialami oleh Guru Mata Pelajaran yang di angkat menjadi Guru BK/Konselor di SMP Muhammadiyah Terpadu tidak diberikan pelatihan Konseling Individual dan dibiarkan berlarutlarut atau tidak diberikan solusinya maka akan berdampak pada perkembangan diri siswa-siswi di Sekolah, tentunya siswa tidak dapat mengembangkan diri secara optimal. Sementara seyogyanya Tugas Konselor di Sekolah dapat membantu siswa dalam mengembangkan potensi yang dimiliki secara optimal. Dalam hal ini peran Konselor di sekolah sangat diharapkan. Maka dari itu tim IbM unihaz memberikan solusi terkait dengan masalah yang dialami oleh Guru Mata Pelajaran SMP Muhammadiyah Terpadu Bengkulu yaitu Pelatihan Layanan Konseling Individual.

\section{METODE}

Kegiatan pelatihan layanan konseling individual bagi Guru Bimbingan dan Konseling SMP Muhammadiyah Terpadu ini dilakukan dari bulan April sampai dengan juli 2019 di ruangan BK SMP Muhammadiyah Terpadu Bengkulu. Kegiatan pelatihan dilakukan sebanyak 9 (sembilan) kali pertemuan. Pertemuan pertama pengisian angket sebelum memulai kegiatan pelatihan, pertemuan ke 2 sampai pertemuan ke enam menjelaskan materi 5 tahapan dalam layanan konseling individual, pertemuan ke tujuh pemutaran vidio konseling individual, pemutaran video ini diberikan setelah selesai materi 5 tahapan dalam layanan konseling individual, guna agar Guru Bimbingan dan Konseling mendapat gambaran dalam melakukan proses konseling dengan menyesuaikan materi 5 tahapan dalam layanan konseling individual. Pertemuan ke delapan melakukan praktek layanan konseling individual, dan pertemuan ke sembilan pengisian angket kembali setelah selesai kegiatan pelatihan. Adapun tahapan kegiatan pelatihan layanan konseling individual yaitu studi pendahulan, penyusunan materi pelatihan, dan pelaksanaan kegiatan pelatihan.

Jumlah peserta pelatihan ini yaitu tiga orang Guru Bimbingan dan Konseling SMP Muhammadiyah Terpadu. Tim Ibm yang akan melakukan kegiatan pelatihan layanan konseling individual ini yaitu Ketua tim Heni Sulusyawati, merupakan sarjana bimbingan dan konseling Fakultas Keguruan dan Ilmu Pendidikan (FKIP) Universitas Prof. Dr. Hazairin, SH (UNIHAZ) Bengkulu, dan Melanjutkan Program Magister Di Fakultas Ilmu Pendidikan (FIP) Jurusan Bimbingan dan Konseling Universitas Negeri Padang (UNP). Mengapuh mata kuliah pada strata 1 BK karier, Konseling Behavioristik, Keterampilan dasar komunikasi. Selain mengajar sering membantu untuk memecahkan permasalahan yang ada kaitannya dengan konseling individual. Dalam bidang pengabdian masyarakat, contohnya 
sosialisasi bimbingan konseling dalam kegiatan seminar, dan mengisi kegiatan konseling di Lembaga Pemasyarakatan (LP).

Juwanto sudah lama menggeluti bidang bimbingan dan konseling. Latar belakang pendidikan adalah sarjana pendidikan Islam yang ditempuhnya di IAIN Batu Sangkar. Melanjutkan program magister di Fakultas Ilmu Pendidikan (FIP) jurusan Bimbingan dan Konseling Universtas Negeri Padang (UNP). Selain mengajar beliau juga banyak melakukan pendampingan konseling di Sekolah dan pendampingan kegiatan Reakreditasi fakultas, prodi yang ada di lingkungan Universitas Prof. Dr. Hazairn, SH Bengkulu.

\section{Studi Pendahuluan:}

Sebelum kegiatan pelatihan dilakukan, tim IbM melakukan studi pendahuluan terlebih dahulu melalui wawancara dan observasi lapangan terkait dengan kondisi mitra sebelum dilakukannya pelatihan. Adapun yang materi yang di observasi dan di wawancarai yaitu proses layanan konseling yang dilakukan selama ini dengan siswa, tahapan yang dilakukan dalam melakukan konseling dengan siswa dan sikap serta prilaku siswa.

\section{Penyusunan Materi Pelatihan:}

Materi yang disiapkan dalam pelatihan di sesuaikan dengan hasil studi pendahuluan, tentunya yang diperlukan oleh mitra, karena berawal dari penguasaan materi untuk menguasai keterampilan. Dalam kegiatan pelatihan ini tim IbM mengacu pada teori Prayitno (2012) mengemukakan bahwa dalam melakukan layanan konseling individual melalui 5 tahapan dalam layanan konseling individual yaitu 1) tahap pengantaran (introduction), 2) tahap penjajakan (investigation), 3) tahap penafsiran (interpretation), 4) Tahap Pembinaan (intervention), 5) tahap penilaian (inspection) dan menggunakan pendekatan behavioristik dalam pandangan behavioral, kepribadian manusia itu hakikatnya adalah prilaku, berupa interaksi antara individu-individu dengan lingkungan sekitarnya wilis (2010). Tidak ada manusia yang sama, karena kenyataannya manusia memiliki pengalaman yang berbeda dalam kehidupannya, dilanjutkan dengan pemutaran vidio layanan konseling individual. Materi dalam pelatihan ini disajikan dan dijelaskan oleh Tim IbM dalam bentuk power point setiap tahapan dalam proses konseling. Salah satu pendekatan yang digunakan dalam proses konseling yaitu Behavioristik, pedekatan behavioristik ini pendekatan mengacu kepada perubahan perilaku. Pendekatan behavioristik ini akan dimasukkan dalam setiap tahapan dalam proses konseling. Dalam pelatihan ini pendekatan behavioristik ini dijelaskan dalam setiap tahapan konseling. Hasil penelitian Erlina dan Fitri (2016) menunjukkan bahwa layanan konseling individual dengan pendekatan behavioristik akan maksimal dengan menekankan pada keterampilan dasar konseling sebagai usaha dalam mengurangi prilaku membolos.

\section{Pelaksanaan Kegiatan Pelatihan}

Adapun metode yang digunakan dalam pelatihan ini yaitu metode cerama, tanya jawab, diskusi, dan praktik. Selain materi yang diberikan dengan peserta, peserta juga diberikan kesempatan untuk tanya jawab dan diskusi, serta praktek konseling individual. Untuk mengevaluasi kegiatan IbM setiap pertemuan Tim IbM menggunakan evaluasi dalam konseling yaitu Laiseg (Penilaian segera) setelah berakhirnya pertemuan peserta diminta untuk memberikan kesimpulan dari materi yang disampaikan, peserta secara langsung akan memberikan kesimpulan tiap pertemuan. Selanjutnya kegiatan praktek konseling individual akan dievaluasi menggunakan penilaian Laiseg juga, setelah peserta melakukan praktek konseling, maka Tim IbM akan mengevaluasi setiap tahapan dalam konseling yang telah dipraktekkan. Selanjutnya Evaluasi secara keseluruhan melalui hasil Pree Tes dan Post Tes. Dengan adanya pelatihan layanan konseling individual ini, diharapkan pemahaman Guru Bimbingan dan Konseling meningkat minimal $75 \%$. Metode yang digunakan dalam pelatihan layanan konseling individual ini, sama dengan metode yang digunakan oleh salmiati, Hasbahuddin, dan Bakhtiar (2018), Hidayat ((2012), dan Sagala, Supriyono, Sutardi, dan Prihanani (2019), yaitu metode ceramah, tanya jawab, dan diskusi.

\section{HASIL DAN PEMBAHASAN}

Berdasarkan persoalan Guru Bimbingan dan Konseling dalam melakukan proses konseling individual dengan siswa, maka tim IbM unihaz menawarkan solusi yaitu pelatihan layanan konseling individual. Solusi yang ditawarkan tersebut dilaksanakan secara sistematis. Kegiatan telah dilaksanakan sampai pada evaluasi kegiatan pelatihan konseling individual. Tim IbM Unihaz juga bersyukur karena diberikan kemudahan dan kelancaran sejak penyusunan proposal hingga pelaksanaan kegiatan IbM.

Pelatihan layanan konseling individual di SMP Muhammadiyah Terpadu Bengkulu, merupakan respons dari Tim IbM Unihaz terhadap pelaksanaan Bimbingan dan Konseling di Sekolah, yakni persoalan Guru Bimbingan dan Konseling dalam melakukan proses konseling dengan siswa. Hal ini disebabkan karena di SMP Muhammadiyah 
Terpadu belum ada tenaga Guru Bimbingan dan Konseling yang berlatar belakang Sarjana Pendidikan Bimbingan dan Konseling, sehingga Guru Mata Pelajaran di angkat menjadi Guru Bimbingan dan Konseling. Selain itu di SMP Muhammadiyah belum ada diberikan pelatihan tentang Tugas Guru Bimbingan dan konseling yang Profesional di Sekolah pada tingkat SMP. Hasil penelitian Jumail (2013) menunjukkan bahwa banyakknya Guru BK/Konselor yang bukan berlatar belakang pendidikan sarjana Bimbingan dan konseling juga berpengaruh terhadap pelaksanaan pemberian layanan. Selanjutnya hasil penelitian Novitasari \& Wibowo (2016) menunjjukkan ada perbedaan yang signifikan antara Guru BK yang berlatar belakang S1 BK dan S1 non BK.

Kegiatan pelatihan telah dilaksanakan sesuai dengan yang direncanakan yaitu selama sembilan hari atau sembilan kali pertemuan. Sembilan kali pertemuan pelatihan ini dilakukan sesuai dengan program yang telah disusun oleh Tim IbM. Penyusuanan program mengacu pada tahapan dalam Layanan Konseling Individual yaitu terdapat lima tahapan dalam Proses Konseling Individual meliputi tahap pengantaran, tahap penjajakan, tahap tahap penafsiran, tahap pembinaan, tahap penilaian, pemutaran video konseling, praktik, dan pre tes dan post tes. Dengan dimulai hari pertama tanggal 20 Mei 2019 diawali dengan pembukaan dan dilanjutkan dengan pengisian angket sebelum memulai kegiatan pelatihan konseling (Gambar 1). Guna untuk mengetahui pemahaman Guru Bimbingan dan Konseling SMP Muhammadiayah Terpadu. Hasil angket sebelum diberikan pelatihan dapat dilihat pada tabel 1. Berdasarkan tabel 1 dapat dimaknai bahwa secara keseluruhan pemahaman Guru Bimbingan dan Konseling SMP Muhammadiyah Terpadu Bengkulu berada pada kategori tidak paham dalam melakukan konseling dengan siswa berdasarkan lima tahapan dalam proses layanan konseling individual, hal itu ditunjukkan oleh hasil persentase capaian 28,70\%.

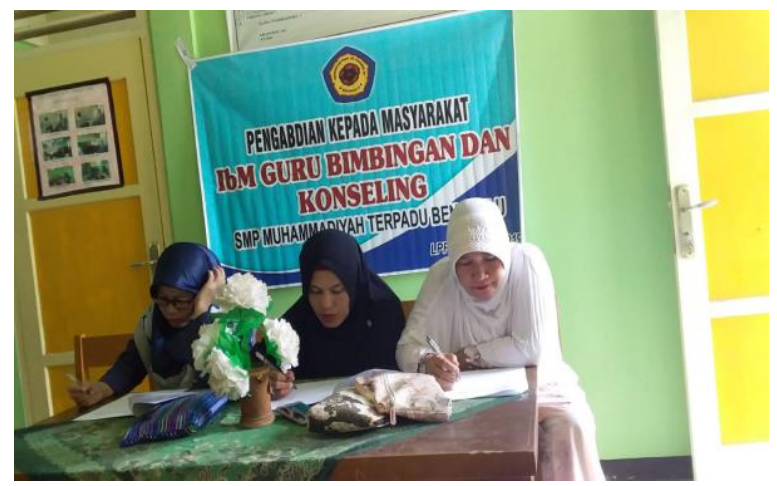

Gambar 1 Pengisian agket sebelum kegiatan pelatihan konseling individual

Tabel 1 Distribusi Frekuensi dan Kategori Pemahaman Guru Bimbingan dan Konseling SMP Muhammadiyah Terpadu sebelum diberikan pelatihan layanan konseling individual.

\begin{tabular}{llcccc}
\hline \multirow{2}{*}{ Interval } & \multirow{2}{*}{ Kategori } & \multicolumn{2}{c}{ Sebelum } & \multicolumn{2}{c}{ Sesudah } \\
\cline { 3 - 6 } & & Frekuensi & Persentase (\%) & Frekuensi & Persentase (\%) \\
\hline $50 \geq$ & Paham & 0 & 0 & 3 & 89,81 \\
$\leq 50$ & Tidak Paham & 3 & 28,70 & 0 & 0 \\
Keseluruhan & & 3 & 100 & 3 & 100 \\
\hline
\end{tabular}

Berdasarkan hasil angket tersebut, maka semakin semangat Tim IbM Unihaz untuk melakukan pelatihan layanan konseling individual menggunakan lima tahapan dalam konseling individual. Hari kedua selasa tanggal 21 sampai hari ke 6 sambtu 25 Mei 2019 kegiatan pelatihan dilakukan dengan pemateri dari Tim IbM Unihaz, selama lima hari kegiatan IbM dilakukan dengan materi lima tahapan dalam layanan konseling individual, tahap satu pengantaran dilakukan pada hari selasa tanggal 21 Mei 2019, tahap ke dua, penjajakan dilakukan pada hari rabu tanggal 22 Mei 2019, tahap ketiga, penafsiran dilaksankan pada hari kamis tanggal 23 Mei 2019, tahap keempat, pembinaan, dilakukan pada hari jum'at tanggal 24 Mei 2019, dan tahap ke lima, penilaian dilakukan pada hari sabtu tanggal 25 Mei 2019. Dalam kegiatan pelatihan terkait dengan materi lima tahapan konseling individual selalu ada kegiatan tanya jawab dan diskusi dengan Guru Bimbingan dan Konseling SMP Muhammadiyah Terpadu (Gambar 2).

Setelah kegiatan pelatihan lima tahapan dalam layanan konseling individual, Tim IbM Unihaz melanjutkan kembali kegiatan pada hari senin tanggal 27 Mei 2019 pemutaran vidio layanan konseling individual. Pada kegiatan pemutaran vidio layanan konseling individula Guru Bimbingan dan konseling Muhammadiyah Terpadu dapat melihat 
dan mendengar secara langsung setiap tahapan yang terdapat dalam layanan konseling individual. Pemutaran video ini dapat membantu Guru Bimbingan dan Konseling menyesuaikan teori yang didapat saat pelatihan yaitu lima tahapan konseling dengan isi vidio layanan konseling individual. Setelah selesai pemutaran video konseling, dibuka sesi tanya jawab untuk membahas isi video tersebut (Gambar 3).

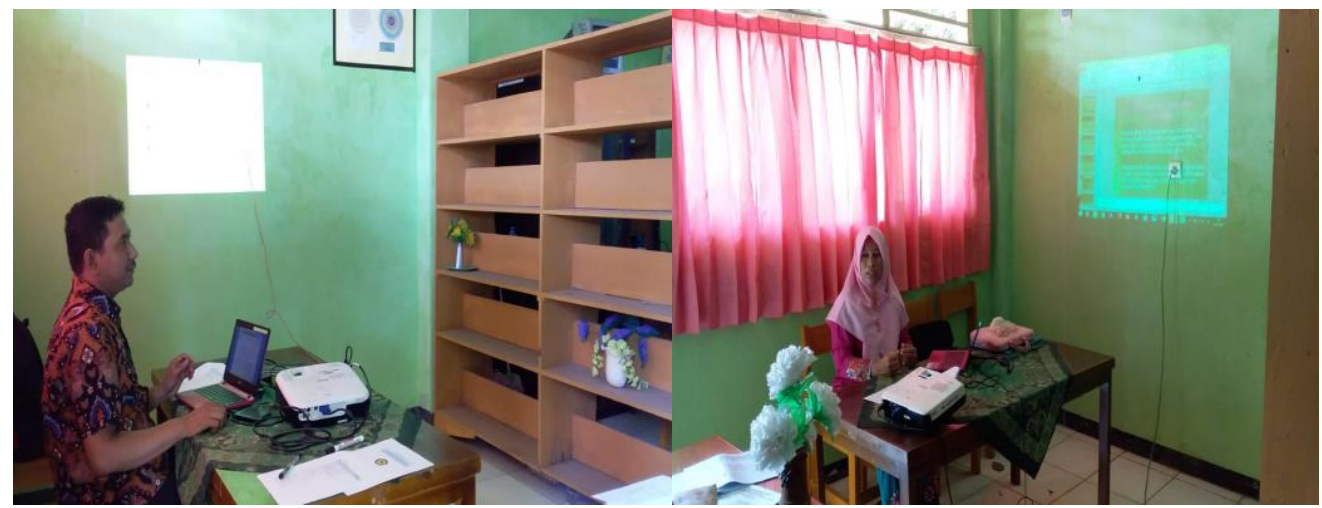

Gambar 2 Penyampaian materi pelatihan konseling individual oleh Tim IbM Unihaz

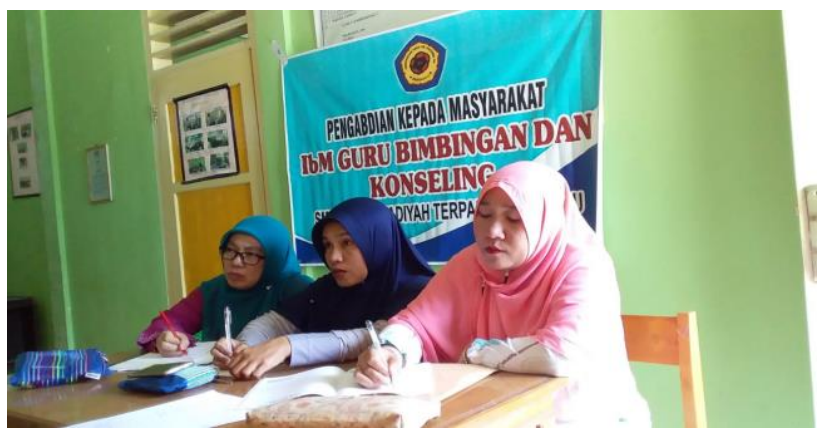

Gambar 3 Proses kegiatan pelatihan layanan konseling individual

Selanjutnya kegiatan praktik konseling individual, yang dilakukan pada hari selasa tanggal 28 Mei 2019. Guru Bimbingan dan Konseling diminta untuk melakukan praktik konseling individual menggunakan lima tahapan dalam proses konseling individual. Guna untuk mengetahui pemahaman Guru Bimbingan dan Konseling SMP Muhammadiyah Terpadu dalam melakukan konseling individual dengan siswa.

Setelah selesai kegiatan pelatihan tahapan konseling individual, pemutaran vidio konseling, praktik konseling individual, terakhir kegiatan dilanjutkan pada hari rabu tanggal 29 Mei 2019. Guru Bimbingan dan Konseling diminta kembali untuk mengisi angket, guna untuk mengetahui secara keseluruhan ada tidanya peningkatan pemahaman Guru Bimbingan dan Konseling SMP Muhammadiyah Terpadu dalam melakukan konseling individual menggunakan lima tahapan dalam konseling individual dengan siswa (Gambar 4).

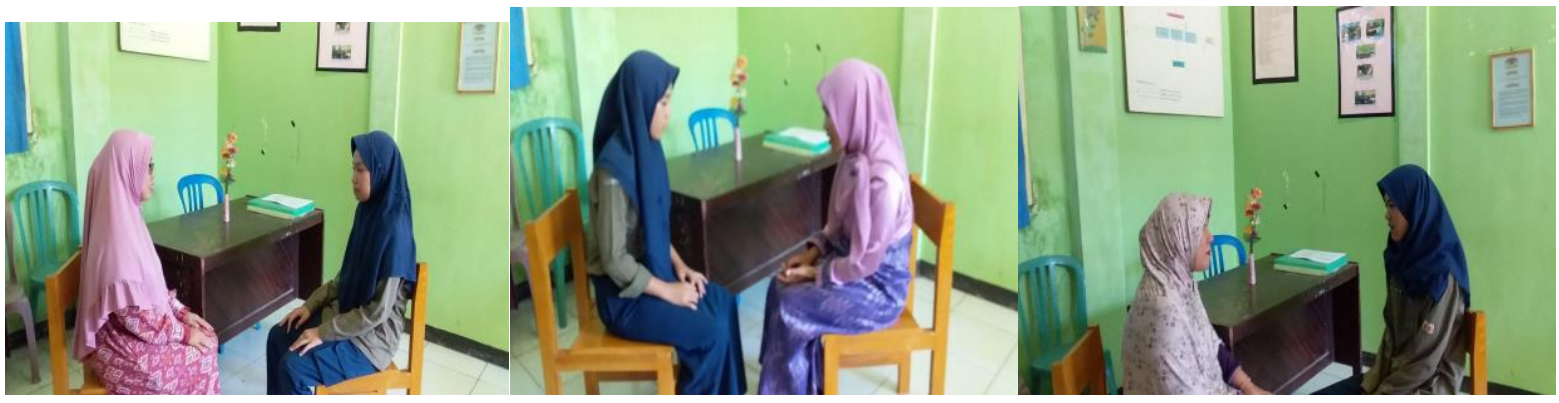

Gambar 4 Praktek konseling individual

Berdasarkan tabel 1 Maka dapat diketahui secara keseluruhan pemahaman dalam melakukan konseling individual menggunakan lima tahapan dalam layanan konseling individual Guru Bimbingan dan Konseling SMP Muhammadiyah Terpadu berada pada kategori paham. Artinya adanya peningkatan pemahaman Guru Bimbingan dan Konseling SMP Muhammadiyah Terpadu dalam melakukan konseling individual menggunakan lima tahapan dalam 
konseling yang dilakukan menggunakan metode ceramah, tanya jawab, diskusi, pemutaran vidio konseling, dan praktik konseling. Hal itu ditunjukkan dari capaian hasil persentase setelah diberikan pelatihan layanan konseling individual menggunakan lima tahapan dalam proses konseling $89,81 \%$.

\section{KESIMPULAN}

Berdasarkan hasil kegiatan pelatihan layanan konseling individual bagi Guru Bimbingan dan Konseling SMP Muhammadiyah Terpadu Bengkulu, yang dilaksankan selama 9 (sembilan) kali pertemuan. Kegiatan pelatihan tersebut diikuti oleh Guru BK dengan penuh semngat dan antusias. Hal itu ditunjukkan dari kedisiplinan Guru BK yang selalu hadir tepat waktu pada saat pelatihan, dan Guru BK juga selalu aktif bertanya pada saat sesi diskusi berlangsung. Sehingga kegiatan pelatihan layanan konseling individual berjalan dengan baik dan sukses. Hal itu juga ditunjukkan dari hasil pengisian angket sebelum diberikan pelatihan layanan konseling individual dengan capaian persentase sebesar $28,70 \%$. Setelah diberikan pelatihan layanan konseling individual adanya peningkatan dengan capaian persentase sebesar $89,81 \%$.

\section{UCAPAN TERIMA KASIH}

Artikel ini merupakan salah satu bagian dari laporan Ipteks Bagi Masyarakat dengan judul IbM Guru Bimbingan dan Konseling SMP Muhammadiyah Terpadu didanai oleh Universitas Prof. Dr. Hazairin, SH melalui Daftar Isian Penggunaan Anggaran Lembaga Penelitian dan Pengabdian pada Masyarakat.

\section{DAFTAR PUSTAKA}

Asmaryadi. (2017). Peran guru bimbingan dan konseling dalam meningkatkan hubungan sebaya mengenai kedewasaan di SMK Muhammadiyah 13 Sibolga. Jurnal Bikotetik: Bimbingan dan Konseling Teori dan Praktik, 1 (1), 15-20.

Adiningtiyas, S. W. (2017) Peran guru dalam mengatasi kecanduan game online. Jurnal KOPASTA, 4 (1), 28 - 40.

Damayanti, F. A \& Setiawati, D. (2013) Studi tentang perilaku membolos pada siswa SMA Swasta Di Surabaya. Jurnal BK UNESA, 3 (1), 454-461.

Erlina, N., \& Fitri, L. Anisa (2016) Penggunaan layanan konseling individual dengan pendekatan behavioristik untuk mengurangi perilaku membolos peserta didik kelas VIII MTs Miftahul Ulum Merabung III Kecamatan Pugung Kabupaten Tanggamus. Konseli: Jurnal Bimbingan dan Konseling (E-Journal), 3 (1), 19-28.

Hidayat, A. Nazmul. (2012) Pengelolaan program bimbingan dan konseling di sekolah menengah atas. Jurnal Pengabdian Kepada Masyarakat, 2 (1), 64-71.

Jannah, N., \& Sari, W. Kartika. (2019) Analisis tingkat kecanduan game pada siswa serta implikasi dalam bimbingan dan konseling. Jurnal Psikodidaktika, 4 (1), 14-19.

Jumail, J. (2013). Kompetensi profesional dalam perspektif guru BK dan peranannya terhadap pelayanan bimbingan dan konseling di SMA Negeri se-Kota Padang. Konselor, 2(1), 250-255.

Novitasai, D., \& Wibowo, M. Eddy. 2016. Perbedaan Kompetensi Guru BK Lulusan S1 BK dan S1 Non BK. Indonesian Jurnal of Guidance and Counseling: Theory and Application, 5 (1), 19-24.

Salmiati., Hasbahuddin., \& Bakhtiar, M. I. (2018) Pelatihan konselor sebaya sebagai strategi pemecahan masalah siswa. MANTAPPA: Jurnal Pengabdian Kepada Masyarakat, 1 (1), 36-41.

Septiana, N. Z. (2019) Perilaku Prososial Siswa Smp Di Era Revolusi Industri 4.0 Kolaborasi Guru dan Konselor. Prosiding Seminar Nasional \& Call Paper Psikologi Pendidikan Fakultas Pendidikan Psikologi. (pp.111-112).

Sagala, D., Supriyono, Sutardi, D., \& Prihanani. (2019). Pelatihan dan pendampingan penulisan artikel ilmiah pada guru sekolah dasar di Kecamatan Air Periukan Kabupaten Seluma Provinsi Bengkulu. Abdihaz: Jurnal Ilmiah Pengabdian pada masyarakat, 1 (1), 1-8.

Stein, D. M., \& DeBerard, S. (2010). Does holding a teacher education degree make a difference in school counselors' job performance?. Journal of School Counseling, 8 (25).

Sofyan, S. W. (2011). Konseling Individual. Bandung: Alfabeta.

Prayitno., Wibowo, M, E., Marjohan., Mugiyarso, H., \& Ifdil. (2015). Pembelajaran Melalui Pelayanan BK Di Satuan Pendidikan. Jakarta: PARAMITRA. 
Heni Sulusyawati \& Juwanto. Abdihaz: Jurnal Pengabdian pada Masyarakat. 2(1):24-30

Prayitno. (2012). Jenis Layanan dan Kegiatan Pendukung Konseling. Padang: Universitas Negeri Padang. 